\title{
Unconventional Gas in Australia: Towards A Legal Geography
}

\begin{abstract}
Recent commentary on future research directions for legal geography highlights the need for studies that are historically grounded and focused on human-environment interactions in rural settings. As a current, controversial land use in Australia, unconventional gas development provides an ideal lens through which researchers can investigate these themes. Utilising emerging international literature and current Australian examples, this paper surveys major trends in the Australian literature relating to unconventional gas (UG), before exploring some of the ways in which Australian legal geographers might contribute constructively to community debates around this resource. Seeking to encourage further analysis, this paper contributes to this developing literature by focussing on two key areas: the various legal actors involved in UG development in Australia (including their regulatory choices, expertise and influence) and the implications for legal geography where attempts are made to establish 'social licence' through contractual arrangements between industry and individual landholders. This article also delves into the place of Indigenous Australians in relation to UG extraction and the questions this resource raises about land use conflicts in Australia more generally - offering suggestions for comparative international studies and further critique at the domestic level.
\end{abstract}

\section{Introduction}

Legal geography is an increasingly dynamic research area, "less a 'field', than braided lines of inquiry that have emerged out of the confluence of various intellectual interests" since the 1980s (Braverman et al., 2014: 1). Arguably not finding its voice as a disciplinary endeavour until 1994, with the publication of Nicholas Blomley's seminal Law, Space and the Geographies of Power (Delaney, 2014), Blomley called for studies that evaluate "the manner in which legal practice serves to produce space yet, in turn, is shaped by a sociospatial context" (1994: 51). In a recent survey of Australian perspectives on the subject, Bartel et al. (2013: 349) concluded that legal geography's "greatest impact is where its focus reveals the importance of scale, time and connection in specific local contexts" and that by "situating law in space, that is within its physical conditions and limits, legal 
geography encourages place-based knowledge to form law's basis". By making this claim, Bartel et al. (2013) extend legal geography's ambitions from that of a sociological critique of the law (eg. Blomley et al., 2001), to advocate for a reconfigured "relation between society and the naturalworld itself" (Graham, 2011: 16).

With this in mind, an attempt is made to selectively assess the extant literature on contested land uses in the form of unconventional gas (UG) in Australia from a legal geography perspective, with a view to identifying the ways in which this discipline might contribute to the public debate surrounding the extraction of this resource. Sources of methane, 'unconventional natural gas' comprises three types: shale gas (SG), coal seam gas (CSG) (also known as coal-bed methane and linked with underground coal seams) and tight gas. All three forms are present within Australia, although their accessibility and commercial readiness vary - with shale and tight gas located within rock formations that pose extraction difficulties (Williams et al., 2012; Measham\& Fleming, 2014). Focussing on possible international comparisons; Conduct and Compensation Agreements in Queensland; mechanisms for litigation; the role of lawyers as multi-faceted contributors to legal geography; legal precedent as a protest strategy around CSG; the role of local government in approving protest camps and questions of compensation, it is argued that there are a variety of disciplinary directions which conceptions of legal geography might reveal. These research pathways are relevant to UG matters in Australia, and may also be applied to other contentious land uses. In setting out their aims for The Expanding Spaces of Law: A Timely Legal Geography, Braverman et al. (2014) contend that silences and gaps abound within the literature of this field. Two are particularly pertinent for this review: the tendency for legal geography writings to exclude the rural from their investigations and to avoid historically-grounded analysis in favour of exploring the connections between contemporary urban spaces and the law. This urban focus does of course have merit in a UG context, such as explaining setback distance ordinances for SG drilling in urban counties of Texas (Fry, 2013). However, within an Australian context, rural areas bear much of the consequences of the UG industry's expansion. Therefore, an increased emphasis on this aspect of the discussion would be beneficial for researchers and the quality of the community debate concerning this resource generally.

Summing up the efforts of legal geography for their own critique of SG regulation in Pennsylvania, Andrews and McCarthy argue that researchers have "paid far too little attention to the environment 
as both an object of governance and a terrain of struggle with respect to the law" (2014: 7). While their absence has been noted in the wider legal geography literature (Delaney, 2001), issues relating to the environment and the place of the law within it have intrigued Australian historical geographers (eg. Stratford, 1993; Holmes, 2000; Stubbs, 2001). More recently, a legal geography slant has proved attractive to those investigating siting disputes through an environmental justice lens (eg. Jessup, 2013). Other socio-legal arenas may assist in informing that research direction in the future (eg. analysis of the Commonwealth's 2007 Northern Territory Emergency Response, see Keenan, 2013 and Crabtree, 2013).

This paper seeks to contribute to this growing research effort, by reviewing some of the ways in which legal geography may assist in developing an understanding of the legal basis for the UG sector in Australia. This includes the manner in which this sector is disputed by pressure groups on a national scale - focusing on two areas in the emerging literature. The first is through studying the types of legal actors involved, their choices, arguments and the influence of their expertise upon regulatory decisions. The second area for focus are the attempts made by companies to achieve a community 'social licence' via contractual agreements with individual landholders, considering also protest strategies employed by social movements to counter such efforts. Other issues are noted, including lobbying efforts to alter the physical extent of regulatory measures for UG and the emerging role of Indigenous people in the development of this industry. Drawing on recent international commentary and using current examples to demonstrate the applicability of this analysis in an Australian context, this paper argues that the opportunities and risks posed by UG development provide an ideal setting for researchers to test various themes in the legal geography literature in greater depth.

\section{Law, geography and unconventional gas}

Mining and UG extraction has engaged the interest of legal geography scholars for some years, with research in the United States examining the historical interconnection between mining law and geography (Matthews, 1997), the present-day competition between mining and Indigenous cultural heritage legislation (Benson, 2012), the power of property law as a source of social disorder in the Appalachian coalfields (Haas, 2008a, 2008b), and the politics of a particular statute and the constitution of expert committees reaching planning decisions (Simonelli, 2014; Hudgins \& Poole, 
2014). Andrews and McCarthy recently combined the analytical tools of legal geography and political ecology to investigate Pennsylvania's Act 13 and its role in facilitating mineral extraction from the Marcellus Shale in the United States by preventing local government control over zoning arrangements for natural gas, making the wider point that: "laws, regulations, policies, and other deployments of state authority are critical to establishing the social and legal spaces in which extractive industries operate" (2014: 7). Australia has yet to be served by similar studies. Much of the popular literature devoted to both coal and UG development in Australia is focussed on the individual experiences of landholders, with a particular emphasis on the efforts of various communities to negotiate (successfully or otherwise) with governments and private corporations (eg. Cleary, 2012; Munro, 2012; Pearse et al., 2013; Manning, 2012). While the stories revealed are often compilations of news reports and all too frequently utilised for explanatory power rather than critical analysis, there are still numerous glimpses into issues that are a legal geographer's stock and trade: the interconnections between space, society and power.

The above popular accounts are regularly cited within the Australian academic literature (eg. Sherval\& Hardiman, 2014). Similarly to the work of popular authors, academic commentators frequently utilise the near-constant media outpourings surrounding both coal and UG extraction in Australia (eg. McManus \& Connor, 2013; Galloway, 2012) - yet the intended audience of a specialist journal may obviously be quite distinct from a journalist's readership. As an example, the anti-CSG organisation Lock the Gate has figured prominently in much of the Australian literature, yet their organisational materials are only gradually becoming the subject of critical discourse analysis - to highlight the extent to which it distinguishes itself from not only CSG companies, but also the 'growth first' message of the Queensland Government (Mercer et al., 2014). Australian commentators have also shown an interest in gauging community perceptions of natural resource extraction and their capacity to influence social identity (eg. the linking of concerns about land rights with cultural understandings of the landscape, see Lloyd et al., 2013). Others have sought to critique the legal infrastructure of both SG and CSG in Australia, with some international comparisons being made (eg. Hunter, 2011, 2014; Swayne, 2012).

One means of expanding the range of legal geographies displayed in UG disputes is to explore how other disciplines have interpreted the social impact of mineral extraction - such as the social impacts of criminal activity in mining camps, currently a key focus for criminologists (eg. Carrington et al., 2011). Although not without data collection obstacles, the distribution of assault offences, or the 
dynamics of private security contractors acting in a policing function are questions for legal geographers to consider. Doing so may allow the drawing of parallels between Australian and US studies concerning the clout (or otherwise) of physically distant law enforcement agencies in rural settings (Pruitt, 2014).

Distance between land uses is clearly an important part of the UG literature (eg. Fry, 2013), but the concept of scale is also particularly relevant as a gauge of social licence for extractive industries at local and regional levels. In Australia, Lacey and Lamont (2013) have pondered the spatial nature of over 4000 Landholder Access Agreements between landholders and CSG operators in Queensland (Petroleum (Production and Safety) Act 2004 (QId), ss 533-534), questioning whether or not these contractual arrangements - which are functionally akin to an easement (Christensen et al., 2012) are truly reflective of a broader social licence to operate. Even where an Agreement is successfully negotiated, community doubts may linger - as "the land access agreements that might be brokered between individual landholders and CSG companies...are more about one-on-one business deals than broad based social arrangements" (Lacey \& Lamont, 2013; Manning, 2012: 149, 150).

These Agreements result in material consequences for the landscape and the manner in which they are enacted by stakeholders or contested between them is a subject of ongoing deliberation. Recent judicial findings from the Queensland Court of Appeal sought to clarify the types of remedies available to landholders who are not able to successfully negotiate a Conduct and Compensation Agreement with CSG companies. In Australia Pacific LNG Pty Ltd v Golden (2013), Justice Muir ruled that accessing alternative dispute resolution remedies to secure a Conduct and Compensation Agreement, in this case through arbitration, was not possible without both parties consenting to use this form of negotiation (Hough, 2014; Plumb \& Shute, 2014). As legal spaces are founded upon "contested social practices and material realities", litigation has a crucial role to play in the process of maintaining and reworking of space (Jepson, 2012: 616). Landscapes are in many ways legal performances - with law acting as a fusing agent between place and identity (Howe, 2008). Litigation is an integral component of this performance and further research is warranted given the extent of these agreements with landholders.

Benson (2014) builds on this idea by suggesting that the internal "rules of engagement" surrounding formal litigation (eg. standing) are in themselves another facet of "everyday" legal geography - 
veiled though they may be in procedural 'neutrality'. There are certainly many ways in which standing can be analysed in Australia, particularly given its range of applications in recent decades (Douglas, 2006). As an important filtering mechanism in the litigation process, standing is a rule that may involve "sacrificing therule of law, and the protection of individual and corporate interests at the expense of collective interests" (Douglas, 2006: 22). Given this tension, analysis of standing rules from a geographical standpoint could assist in discerning the possibilities of a distinctly 'Australian legal geography' (Bartel et al., 2013). Is Australia's litigation process illustrative of a unique perspective, or can comparative studies with other jurisdictions (eg. Benson, 2014) highlight similarities between Australian environmental standing decisions and international equivalents? What are the implications for public participation in different landscapes? In light of recent calls to embrace the comparative potential of legal geography (Braverman et al., 2014), the time may be ripe for posing these types of questions.

Accepting that the "everyday" aspects of litigation are an underutilised component of the legal geography literature (Benson, 2014: 218), these "rules of engagement" can be seen through the prism of UG disputes in Australia. For example, the New South Wales Office of Coal Seam Gas recently decided to suspend their approval for the company Metgasco to drill an exploration well at Bentley near Casino in the Northern Rivers region of the state, "on the basis that the company was not in compliance with its community consultation obligations" (New South Wales Office of Coal Seam Gas, 2014). Metgasco has responded in turn by seeking judicial review of the suspension (Metgaasco, 2014), therefore there may be an opportunity to combine the growing literature around the importance of community engagement in CSG developments with legal analysis of conditions attached to an exploration licence (ABC News, 2014d).

Another example could be an examination of the rule of evidence known as discovery. Although a seemingly benign mechanism for ensuring that all parties exchange relevant documentation prior to the closing of litigation pleadings, when the rule's adversarial context is acknowledged, it may also assume contested meanings. The instrument of discovery may be both a step towards answering questions of possible contamination of water bores near the Pilliga State Forest in the public interest for the people of New South Wales (the view of the NSW Environmental Defenders Office), or serve, according to the company Santos, as an irrelevant data-gathering exercise for potential litigation in the future (EDO NSW, 2014; Herbert, 2014a). Differing interpretations are of course at the heart of 
the law's operation, with lawyers serving as both translators and creators of legal language and everyday discourse (Sugarman, 1994).

Beyond land access concerns, the impact of CSG operations on the real estate market in New South Wales has attracted media (ABC News, 2014a) and academic commentary (Fibbens et al., 2013, 2014). Speaking on the Hunter Valley real estate market recently, the State Valuer General, Phillip Weston, stressed the challenges of determining the causes behind property sale delays, on account of both coal and CSG development in the region. Weston acknowledged that the immature nature of the CSG industry in NSW also made this type of research difficult, but confirmed that: "There seems to be some anecdotal evidence from property professionals there has been some changes in terms of the length of time it's taking for properties to sell" (ABCNews, 2014a). For Fibbens et al. (2013, 2014), there remain ongoing questions surrounding the compensation regime of the Petroleum (Onshore) Act 1991 (NSW) as raised by CSG extraction. While the occupation of land by CSG operators is not equated with acquisition of freehold title, a company's operations require access arrangements between themselves and landholders that "tie up land for the term of occupation" an inherently uncertain length of time, ranging from 20-40 years on some estimates and are ultimately subject to the economic viability of the resource itself (Fibbens et al., 2013, 5).

Drawing on compensation and valuation theory, Fibbens et al. (2013) argue that the New South Wales legislative framework for mining operates on a preconceived notion that all exploration activities are temporary (Petroleum (Onshore) Act 1991 (NSW), s 107) - thereby affecting the manner in which compensation is considered. They find the legislation wanting on several grounds, including loss of business goodwill and special value (land having value to an owner due to some "attribute or use made of the land") (Fibbens et al., 2013: 7, 11-12). Given media coverage of CSG exploration and its possible influence on tourism numbers (Schweinsberg \& Wearing, 2013), could negative publicity prompt a law reform argument for loss of business goodwill (Fibbens et al., 2014)? Other openings for discussion are raised:

A great deal of research remains to be done in the area of compensation for coal seam gas occupation. Further research into the affect of access arrangements and CSG infrastructure is needed. In NSW, this will necessarily be of a qualitative nature pending the expansion of CSG well fields and the transaction of properties affected by 
Internationally, SG development presents its own series of 'what if?' scenarios for US valuers (Lipscomb et al., 2012).Despite cross-fertilisation potential, Kedar (2014) has described the dearth of comparative research outputs from legal geographers as a significant challenge for the field. Attempts at a comparative approach are clearly not without difficulties. For example, a US study of landowner coalitions seeking to collectively bargain with natural gas companies to draw up legally binding leasesseems unlikely to find an Australian equivalent (Jacquet \& Stedman, 2011), because mineral subsurface rights in the United States - unlike the situation in Australia - are primarily held by private landholders. The global distribution of legal geography researchers presents another challenge, with scholarly efforts largely confined to precedent-focused common law countries leading to a methodology bias against code-based civil law traditions (Kedar, 2014; Villanueva, 2013: 36). However, the use of moratoria by state governments in both the US and Australia to prevent and postpone UG development is one fruitful comparative pathway, with only limited critique of moratoria in New York State (Simonelli, 2014) and mixed media coverage in Australia (eg. Carter, 2014; King et al., 2013; McGauran, 2013). Any comparative research would need to acknowledge differing political contexts, with some countries more wary of UG development than others perhaps due to a desire to protect their status as renewable energy innovators, as Denmark has shown (Becker \& Werner, 2014).

Enlivening the literature with the viewpoints of different types of legal regimes could form part of another research direction. Comparing Australian and Indonesian legislative responses to a growing UG industry is one possibility (for an Indonesian perspective, see Godfrey et al., 2010). It is also worth pointing out that geographers have already shown some of the potential rewards for posing comparative questions, for example, through the relevance of competing cartographic interpretations for offshore oil and gas negotiations between Australia and East Timor (Nevins, 2004). Aside from town planners and valuation experts, another constituency in the Australian UG debate that should be part of any research agenda are legal practitioners themselves.

\section{Legal practitioner perspectives}


Socio-legal researchers have long recognised that lawyers occupy a privileged, multifaceted position in society, as both officers of the legal system and an all-important link between the courts and the wider population (Ingleby \& Johnstone, 1995). Their capacity to engage across these arenas can be seen in the realms of policy reform, legislative drafting, and litigation advocacy - with legal professionals often wearing many hats (Tomasic, 1978). Geographers have certainly recognised that law is "too important to be left to the lawyers" (Friedman, 1986: 780), but researchers have remained reluctant to engage systematically with the legal profession. Nonetheless, legal professionals exert considerable influence as "constituents of landscape" (Martin \& Scherr, 2005: 379). In wider socio-legal research, members of the legal profession have offered their voices to substantiate research questions in the past. Occasionally this has taken on a geographical component, as seen Smith's (2006) study of Australian criminal defence lawyers and their motivations for representing the unpopular. Others have considered the impact of geography as a factor in the transplantation of legal precedent among Australia's state courts (Smyth \& Mishra, 2011). These studies could well be considered cases of legal geography in all but name, as many authors would not see themselves as legal or geography practitioners (Blomley, 2003a).

While the perspectives of legal practitioners can be seen in a variety of sources relating to UG in Australia, from interviews with the media (Locke, 2014), Parliamentary inquiries (De Rijke, 2013a), legal determinations (Plumb \& Shute, 2014) and professional journals (Christie, 2012), as a group, legal practitioners are not generally seen as influential actors in directing the outcome of land-use disputes. This is despite their often central place in attempting to resolve contested legal and political claims (Martin et al., 2010). They can do this by deploying arguments and language against judges in order to persuade and create physical effects upon the world (Delaney, 2010).

Despite this recognition, Deborah Martin and colleagues have correctly identified that both lawyers and "the practice of the law" are generally missing from the growing output of the legal geography project (Martin et al., 2010: 176). Viewing lawyers and judges as "nomospheric technicians" (Delaney, 2010: 158, 159) is one means of analysing legal professionals and their litigation/adjudication strategies through a legal geography framework. This term is an element of Delaney's wider nomospheric investigations research and a response to Nicholas Blomley's earlier call for researchers to create a conceptual language "that allows us to think beyond binary 
categories such as 'space' and 'law'" (Blomley, 2003b: 29-30). For Delaney, the "nomosphere" amounts to "the cultural-material environs that are constituted by reciprocal materialization of 'the legal' and the legal signification of the 'sociospatial', and the practical, performative engagements through which such constitutive moments happen and unfold" (2010: 25). Applying his concept to legal professionals, or 'technicians' of the nomosphere, Delaney links the actions of these key actors with changes in geographical space:

[W] hat nomospheric technicians do can be thought of as a kind of fabrication process, where raw materials are brought together and worked on, and which results in the construction of nomospheric world-models. These...representations are fabricated in order to be presented in ritual, institutional settings to other nomospheric technicians (judges). The job of judging essentially entails the assessment of the relative merits of contending world-models according to a range of criteria. Judges disqualify one, and validate another...These arguments as world-models are not offered [by lawyers] for the purposes of contemplation or admiration. They are designed to have cognitive and affective effects on judges and practical effects in the world. They are pragmatically fabricated in order to persuade - to cause an empowered state actor to see the world in a particular way [and act accordingly] (2010: 159-160. Emphasis in original.)

As a new development in the literature, it may be some time before the potential of legal practitioners as a research source is fully realised. While acknowledging that Martin's challenge should be responded to, possibly through the lens of Delaney'sworld-making nomosphere, there is even greater scope to include individuals from all levels of legal practice in this analysis, not just lawyers: from law students to judges, legal academics, in-house company counsel and bureaucrats. This is illustrated by the public unease associated with CSG development and competing community narratives of place in rural centres (eg. Sherval \& Hardiman, 2014). As noted above, the perspectives of individuals involved in the legal process are to be found in many places, from media coverage of self-represented litigants recalling their experiences in the Queensland Land Court (Calderwood, 2014), popular texts on coal development in Australia (Munro, 2012; Manning, 2012: 10), industry journals containing commentary on the latest regulatory developments (Plumb, 2013; Hoare et al., 2014; Brockett, 2014), speeches, policy submissions and scholarly articles by judges and barristers (eg. Christie, 2012). Then there are the more obvious contributions of legal judgments and draft legislation. Geographers and legal commentators have themselves utilised the power of interviews for their own research, enriching their analysis beyond purely regulatory matters in the process (Sherval \& Graham, 2013). Keeping an open mind as to the all-encompassing impact of legal 
relations is beneficial to the researcher, as clearly lawyers are not the only professional group responding to the challenges of UG - a point Delaney underscores:

We need to think about the legal in more performative and material terms...[T]he legal is continuously performed, re-enacted....and creatively done and redone. The legal is always happening. It is performed, not only by those we identify as "legal actors (police, guards...and diplomats) but by everyone who acts in accordance with (or with transgressive reference to) understandings of rules, authority, rights, permissions, prohibitions, duties and so on. (Emphasis in original), (2010: 19).

Beyond individual actors, legal structures are bound more generally to community understandings of a nation's cultural heritage. Australia's legal history and the contemporary conditions of Indigenous Australians are not necessarily new ground for legal geographers (Bartel et al.,2013), but integrating these issues into the broader context of extractive industries in Australia is another avenue for researchers to wander.

\section{Legal history and contemporary Indigenous perspectives}

Political campaigns surrounding contested land uses are not a new phenomenon in Australia. As the latest resource to court controversy, the exploitation of UG offers historically-minded legal geographers the opportunity to reflect more critically upon competition between private property interests. While CSG development in particular has been credited with altering previously-held community beliefs about State ownership of mineral resources (Organ, 2014), this "modern property law conundrum" (Weir \& Hunter, 2012) has an historical twist:

Ironically, the exercise by miners of CSG rights is in direct contrast to the mining industry's widely publicised untruthful objections to native title following the Mabo and Wik decisions [in 1992 and 1996 respectively]. Aggressive national campaigns were run at the time, warning freehold landowners of the threat that native title posed to the maintenance and exercise of private property rights. Native title, that most fragile of all property rights, was never contemplated as being in competition with freehold title in spite of the miners' claims. In contrast, CSG rights directly and explicitly collide with what...[Blackstone called] 'the highest and most extensive interest that a man [sic] can have' in land (Galloway, 2012: 79). 
Indigenous Australians have certainly featured strongly in critiques of the mining industry (eg. Pearse et al., 2013; Cleary, 2012). They may also have a significant role to play in discussions around UG in Australia, depending on drilling locations. A future example of this may potentially be seen at Mount Mulligan (Nguddaboolgan), 100 kilometres west of Cairns (Figure 1). An impressive natural landmark of sandstone cliffs, coal deposits beneath the mountain supported a mining community from 1914 to 1958. Entering a new phase as a cattle property (Bell, 1978), it now serves as a hobby farm. Mount Mulligan is also entrenched in North Queensland folklore as the scene of Queensland's worst land disaster, a massive coal dust explosion on 19 September 1921 that resulted in the deaths of all 75 men and boys working underground (Bell, 1978, 1996, 2013). PubMed Significant for its Indigenous prehistory, archaeological evidence of human habitation in rock shelters of the mountain date to 37,000 years (Bell, 1996).

[Figure 1: Map of Trafford Project. Source: Mantle Mining Corporation, 2014a: 7.]

From 1991, Mount Mulligan was owned by the Western Yalangi Aboriginal Corporation and leased to the Queensland Department of Environment and Heritage as the Kuku Djugan Nurrabullgin National Park (Bell, 1996). In August 2012, the Djugan people were granted native title interests over the site by the Federal Court, permitting them exclusive use of approximately 149,915 hectares in and around the mountain (Archer on Behalf of the Djungan People \# 1 v State of Queensland, 2012; Queensland Government, 2012). The area is once again generating interest due to a coal and CSG exploration licence being granted to Mantle Mining Corporation, a Perth-based company, in 2008. The company's initial four-year exploration permit was recently extended by the State Government to 4 December 2015 and relates to a 5,500sq km area surrounding Mount Mulligan. Initially, an Indigenous Land Use Agreement was executed with the Djungan people, who formed a Coordinating Committee to work with Mantle Mining to progress exploration plans and manage Indigenous cultural heritage (Mantle Mining Corporation, 2012, 2014a, 2014b). This Committee had a leading role in finalising a Conduct and Compensation Agreement that was entered into by the Djungan people and Mantle Mining in November 2013 (Mantle Mining Corporation, 2013).

In a place alive with legends and cultural heritage - dealing with both the disaster (Bell,1979-1980) and the origins of the mountain itself in Indigenous oral tradition - the extension of Mantle Mining's 
licence has caused some consternation. Traditional owners held a public meeting at Mareeba on 28 May, 2014, to discuss the company's intended operation - expressing concern at the potential for contamination of underground aquifers and urging Mantle Mining to negotiate with them to secure an access agreement (Cluff, 2014; Reghenzani \& Vlasic, 2014). With presentations from visiting residents of Chinchilla, solicitors from the North Queensland EDO, Federal and State politicians and key members of Lock the Gate, further discussion is planned (North Queensland Lock the Gate Alliance Affiliate Group, email 9 June 2014). Whether this represents the type of contractual agreement versus social licence conundrum suggested above by Lacey and Lamont (2013) remains to be seen.

This brief overview hints at how sites such as Mount Mulligan present possibilities for researchers examining UG development in a local Australian context. As landscapes are partly influenced by community perceptions of the law, the manner in which the UG industry is implemented may vary between localities - notwithstanding the legislative intent of central government (Jones, 2006). Researchers may choose to consider this further, with rural areas arguably distanced - both physically and socially - from the "force of the state" as a source of legal order (Pruitt, 2014: 190). Consequently, negotiations across multiple scales and jurisdictions are commonplace.

\section{Scale and spill-over}

The spatial and categorical obsessions of both law and property have been recognised by legal geographers for some time (eg. Blomley, 2005; Dorsett \& McVeigh, 2002). Extractive industries are also notable for their ability to affect regions in a spatially uneven manner, with the law serving as an instrument in this process of social construction (Haas, 2008b). If the notion of jurisdiction is understood to be "law's territory" (Ford, 1999), then the use of legal authorities as a protest strategy against coal and CSG development by Lock the Gate presents another research question for legal geographers (Figure 2). The High Court's decision in Plenty $v$ Dillon involved the failure of two police officers to provide a search warrant to Plenty before entering their premises, and their finding of trespass seems far removed from the efforts to halt mining operators (1991: 635). But this has not prevented its symbolic use by protestors - combining a physical barrier with a jurisdictional challenge. Social spaces and boundaries are of course "saturated" in legal meanings and often subject to "divergent interpretations" (Blomley et al., 2001: xviii). In addition to being a ubiquitous 
presence in the world (as Austin Sarat famously observed: "law is all over", quoted in Delaney, 2003: 67), law is also a tool through which protest action can be mobilised for particular ends. The symbolic politics of property is a theme to be found across the world and is clearly not limited to extractive industries (eg. Brower et al., 2009; Blomley, 1998).

[Figure2: Invoking boundaries as a protest strategy. Source: Lock the Gate Alliance, 2014.]

The extent of law's reach in society makes it an attractive weapon for protest groups, yet its deployment remains contingent upon geographical context (Akinwumi, 2012). Interpretation and prioritisation of different geographical scales can be relevant for framing community dissent and ultimately the legal basis for development approvals (Jessup, 2013). Jurisdictional choices by regulators can also be a source of dispute, as farmers in the Pilliga Forest region of New South Wales recently discovered, after the CSG operator Santos was fined $\$ 1500$ by the NSW Environmental Protection Agency for failing to prevent a uranium spill into a local aquifer - a leakage found by Santos itself and reported accordingly. Although the regulator also imposed a pollution reduction program upon Santos, forcing the company to improve monitoring and remediation infrastructure at the site, for some observers this was not a sufficient penalty, leading to questions about its regulatory approach: "[F]armers and environmental groups say the EPA has failed its charter. They say if Santos had been forced to go before the Land and Environment Court, it could have been liable to penalties of up to a million dollars" (Cornwall, 2014).

It is stressed that the law's geographical impact can be shaped by any number of stakeholder perspectives, not just those who protest the existence of the UG industry. The spatial extent of the sector has been noted widely in the literature, both within Australia and overseas (eg. Measham \& Fleming, 2014; Stedman et al., 2012). Less attention has been directed to stakeholder efforts to mould the State's regulatory response to this expansion. For example, alleged lobbying by the resource company Santos to modify the geographical range of a then draft New South Wales Strategic Regional Land Use Policy (released in 2012) suggests there is more to be said about how regulatory choices regarding the industry are made and what influences may underpin them (Lamacraft, 2014). 
Landholders have demanded the legal right to refuse entry to CSG operators at a Parliamentary level (Galloway, 2012), but seem to have had more success with their argument when particular companies have declared that they will not seek to establish themselves where they are deemed unwanted (eg. the land access agreement reached between Santos, AGL, the NSW Irrigators Council and Cotton Australia in March this year: Herbert, 2014b, see also the subsequent discussions between Dairy Connect and AGL at Gloucester in New South Wales, ABC News, 2014c). These industry arrangements can of course be seen as an effort to construct a social licence to operate and avoid reputational damage to a company's image (Tuck, 2012), but the protest strategy itself has not (as yet) resulted in formal legal change by government. The spatial presence of protests against CSG development can also be found in the local government approvals for protest camps - as demonstrated by the non-renewal of a permit to expand a protest camp at Bentley, New South Wales. As explained by the Richmond Valley Council, existing uses of the landscape and public health concerns were key considerations:

[Their] application... has been opposed by people who have a fairly strong influence, such as the police...R[oads and] M[aritime] S[ervices] and our plannersthemselves...It unfortunately is not of an appropriate quality and the proposed use will not be approved...As it's grown... it's become something different from a primitive site...There are many, many aspects of the conditions that were applied to it that are not being adhered to, and it's just an inappropriate mechanism for any approval (ABC News, 2014b).

The above shows that in defining the boundaries and uses of landscapes, some specialist groups have considerable power - despite the fact that local government in Australia is generally perceived to be excluded from decision-making processes around UG (De Rijke, 2013b). However their role may be of increasing relevance, given the use of referendum-style polling on CSG developments in local government areas (Luke et al., 2014). UG extraction raises jurisdictional questions that traverse far more than compensation, land access and environmental harms - partly because of its relatively short commercial existence in Australia (Keogh, 2013). It therefore has the potential to create new legal frontiers.

\section{Conclusion}


As shown above, there are many ways in which legal geography might contribute to the ongoing public debate in Australian around UG extraction. Researchers may choose to approach this challenge by studying the types of legal actors involved, their choices, arguments and the influence of their expertise upon regulatory decisions. Alternatively, ongoing CSG development presents opportunities for companies attempting to achieve community social licence via contractual agreements with individual landholders - and for the use of boundaries as a protest strategy to counter such efforts. The physical extent of regulatory measures may also be influenced by lobbying from any number of interested parties, including Indigenous people. In the search for extractive models, further analysis of the comparative type undertaken by Hunter (2014) is warranted to assess whether Australia's regulatory regimes are appropriate for the minimisation of social, economic and environmental costs - no easy task where energy law and policy is concerned. With both "unique and universal truths" surrounding issues of compensation, litigation processes, land valuation and Indigenous perspectives (Bartel et al., 2013: 348) - Australian commentators are encouraged to embrace the opportunity to compare these questions while addressing their domestic circumstances. Perhaps most importantly, the controversy of UG extraction invites wider questions about resource use and the linkages between space, power and society as a whole.

\section{References}

ABC News, 2014a: More Research Needed on Impact of CSG Land Sales, 13 May 2014. Retrieved 15 May 2014 from <http://www.abc.net.au/news/2014-05-13/more-research-needed-on-impact-ofcsg-on-land-sales/5448480>.

ABC News, 2014b: Council to withdraw approval for anti-CSG protest camp, 23 April 2014. Retrieved 25 April 2014 from <http://www.abc.net.au/news/2014-04-23/protest-camp/5407434>.

ABC News, 2014c: Dairy Farmers and Gas Industry Giant Sign New Cooperation Agreement, 29 May 2014. Retrieved 30 May 2014 from <http://www.abc.net.au/news/2014-05-29/dairy-farmers-andgas-industry-giant-sign-new-cooperation-agree/5485554>.

ABC News, 2014d: Metgasco says it was assured of government support prior to gas drilling licence suspension, 24 July 2014. Retried 25 July 2014 from <http://www.abc.net.au/news/2014-0724/metgasco/5620618>. 
Akinwumi, A., 2012: Powers of Reach: Legal Mobilization in a Post-Apartheid Redress Campaign, Social and Legal Studies 22, 25-41.

Andrews, E. and McCarthy, J., 2014: Scale, Shale, and the State: Political Ecologies and Legal Geographies of Shale Gas Development in Pennsylvania, Journal of Environmental Studies and Sciences 4, 7-16.

Archer on Behalf of the Djungan People \#1 v State of Queensland [2012] Federal Court of Australia 801, 2 August 2012. Retrieved 30 May 2014 from <http://www.austlii.edu.au/au/cases/cth/FCA/2012/801.html>.

Australia Pacific LNG Pty Ltd v Golden and Others [2013] Queensland Court of Appeal 366, 9 December 2013. Retrieved 10 May 2014 from <http://archive.sclqld.org.au/qjudgment/2013/QCA13-366.pdf>.

Bartel, R., Graham, N., Jackson, S., Prior, J.H., Robinson, D., Sherval, M. and Williams, S., 2013: Legal Geography: An Australian Perspective, Geographical Research 51, 339-353.

Becker, V. and Werner, A., 2014: One Step Forward, One Step Backward: Shale Gas Development in Denmark and Sweden, Journal of European Management and Public Affairs Studies 1, 23-30.

Bell, P., 2013: Alas It Seems Cruel: The Mount Mulligan Coal Mine Disaster of 1921. Boolarong Press, Brisbane.

Bell, P., 1996: "If Anything, Too Safe": The Mount Mulligan Coalmine Disaster of 1921. Department of History and Politics James Cook University of North Queensland, Townsville.

Bell, P., 1979-1980: "If You Take Something From Mother Earth, She Will Retaliate": Legends From the Mt. Mulligan Coal Mine Disaster, Royal Historical Society of Queensland: Historical Papers 40, 89102.

Bell, P., 1978: The Mount Mulligan Disaster. History Department James Cook University of North Queensland, Townsville. 
Benson, M.H., 2014: Rules of Engagement: The Spatiality of Judicial Review. In I. Braverman, N. Blomley, D. Delaney and A. Kedar (eds) The Expanding Spaces of Law: A Timely Legal Geography. Stanford University Press, Stanford, 215-238.

Benson, M., 2012: Mining Sacred Space: Law'sEnactment of Competing Ontologies in the American West, Environment and Planning A 44, 1443-1458.

Blomley, N.,2005: Flowers in the Bathtub: Boundary Crossings at the Public-Private Divide, Geoforum 36, 281-296.

Blomley, N., 2003a: Law, Property, and the Geography of Violence: The Frontier, the Survey and the Grid, Annals of the Association of American Geographers 93, 121-141.

Blomley, N., 2003b: From 'What?' To 'So What?': Law and Geography in Retrospect. In J. Holder and C. Harrison (eds) Law and Geography: Current Legal Issues 2002 Volume 5. Oxford University Press, Oxford, 17-33.

Blomley, N., 1998: Landscapes of Property, Law and Society Review 32, 567-612.

Blomley, N., 1994: Law, Space and the Geographies of Power. The Guilford Press, New York.

Braverman, I., Blomley, N., Delaney, D. and Kedar, A., 2014: Expanding the Spaces of Law. In I. Braverman, N. Blomley, D. Delaney and A. Kedar (eds) The Expanding Spaces of Law: A Timely Legal Geography. Stanford University Press, Stanford, 1-29.

Brockett, R., 2014: Moving Forward with Unconventional Gas, Water: Journal of the Australian Water Association 41, 46-50.

Brower, A., Page, J., Kennedy, A. and Martin, P., 2009: The Cowboy, The Southern Man, And The Man From Snowy River: The Symbolic Politics of Property in Australia, The United States, and New Zealand, Georgetown International Environmental Law Review 21, 455-493. 
Calderwood, K., 2014: Milestone for Self-Represented Landholder in Court, ABC Rural, 30 April 2014. Retrieved 30 April 2014 from <http://www.abc.net.au/news/2014-04-08/alpha-coalproject/5378530>.

Carrington, K., Hogg, R. and McIntosh, A., 2011: The Resource Boom's Underbelly: Criminological Impacts of Mining Developments, Australian and New Zealand Journal of Criminology 44, 335-354.

Carter, J., 2014: Onshore Gas Fears For Farmers, ABC Rural, 12 June 2014. Retrieved 12 June from <http://www.abc.net.au/news/2014-06-12/onshore-gas-fears-for-farmers/5518690>.

Christie, E., 2012: Coal Seam Gas Development, Environmental Legislation and Power, Towards a Pathway for Conflict Resolution and Environmental Justice, Queensland Lawyer 32, 225-247.

Christensen, S., O'Connor, P., Duncan, W.D. and Phillips, A., 2012: Regulation of Land Access for Resource Development: a Coal Seam Gas Case Study from Queensland, Australian Property Law Journal 21, 110-146.

Cleary, P., 2012: Mine-Field: The Dark Side of Australia's Resources Rush. Black Inc, Collingwood.

Cluff, R., 2014: Indigenous Group Fears CSG Impact on Mount Mulligan Water, ABC Indigenous, 28 May 2014. Retrieved 30 May 2014 from <http://www.abc.net.au/news/2014-05-28/indigenousgroup-fears-csg-impact-on-mount/5483102>.

Cornwall, D., 2014: Coal Seam Gas in NSW Unites Farmers and Green Groups, ABC PM, 10 March 2014. Retrieved 10 March 2014 from <http://www.abc.net.au/pm/content/2014/s3960379.htm>.

Crabtree, L., 2013: Decolonising Property: Exploring Ethics, Land, and Time, Through Interventions in Contemporary Australia, Environment and Planning D 31, 99-115.

Delaney, D., 2014: Legal Geography I: Constitutivities, Complexities, and Contingencies, Progress in Human Geography doi: 10.1177/0309132514527035. 
Delaney, D., 2010: The Spatial, the Legal and the Pragmatics of World-Making. Routledge, New York.

Delaney, D., 2003: Beyond the Word: Law as a Thing of This World. In J. Holder and C. Harrison (eds) Law and Geography: Current Legal Issues 2002 Volume 5. Oxford University Press, Oxford, 67-83.

Delaney, D., 2001: Making Nature/Marking Humans: Law as a Site of (Cultural) Production, Annals of the Association of American Geographers 91, 487-503.

Delaney, D., Ford., R. and Blomley, N., 2001: Preface: Where Is Law?. In N. Blomley, D. Delaney and R.T. Ford (eds) The Legal Geographies Reader: Law, Power, and Space. Blackwell, Oxford, xiii-xxii.

Dorsett, S. and McVeigh, S., 2002: Just So: "The Law Which Governs Australia is Australian Law", Law and Critique 13, 289-309.

Douglas, R., 2006: Uses of Standing Rules 1980-2006, Australian Journal of Administrative Law 14, 22-37.

EDO NSW, 2014: Farmers Seek Court Order for Santos Water Monitoring Data, 26 May 2014. Retrieved 26 May 2014 from <http://www.edonsw.org.au/farmers seek court order for santos water monitoring data>.

Fibbens, M., Mak, M. and Williams, A., 2014: Compensation for Coal Seam Gas Occupation: Assessing the Harms, paper presented at the 20th Pacific Rim Real Estate Society Conference, 19-22 January 2014, Lincoln University, Christchurch, New Zealand, 1-12. Retrieved 29 March 2014 from $<$ http://www.prres.net/papers/Fibbens Compensation CSG Occupation.pdf>.

Fibbens, M., Mak, M. and Williams, A., 2013: Coal Seam Gas Extraction: Does Landholder Compensation Match the Mischief?, paper presented at the $19^{\text {th }}$ Pacific Rim Real Estate Society Conference, 13-16 January 2013, RMIT University, Melbourne, Australia, 1-14. Retrieved 29 March 2014 from <http://www.prres.net/papers/Fibbens Coal seam gas extraction.pdf>.

Ford, R., 1999: Law's Territory (A History of Jurisdiction), Michigan Law Review 97, 843-930. 
Friedman, L., 1986: The Law and Society Movement, Stanford Law Review 38, 763-780.

Fry, M., 2013: Urban Gas Drilling and Distance Ordinances in the Texas Barnett Shale, Energy Policy 62, 79-89.

Galloway, K., 2012: Landowners' vs Miners' Property Interests: The Unsustainability of Property as Dominion, Alternative Law Journal 37, 77-81.

Godfrey, P., Ee, T. and Hewitt, T., 2010: Coal Bed Methane Development in Indonesia: Golden Opportunity or Impossible Dream?, Journal of Energy and Natural Resources Law 28, 233-264.

Graham, N., 2011: Lawscape: Property, Environment, Law. Routledge, Oxford.

Haas, J., 2008a: Law and Property in the Mountains: A Political Economy of Resource Land in the Appalachian Coalfields, PhD thesis, Ohio State University, Columbus. Retrieved 16 July 2014 from <https://etd.ohiolink.edu/rws etd/document/get/osu1204466619/inline>.

Haas, J., 2008b: Law of Regions: Mining Legislation and the Construction of East and West. In M.K. Goodman, M.T. Boykoff and K.T. Evered (eds) Contentious Geographies: Environmental Knowledge, Meaning, Scale. Ashgate, London, 187-199.

Herbert, L., 2014a: Santos Claims Legal Action is a 'Data Crawl', ABC Rural, 26 May 2014. Retrieved 26 May 2014 from <http://www.abc.net.au/news/2014-05-26/santos-responds-farmer-claimswater-contamination/5477226>.

Herbert, L., 2014b: Santos and AGL Sign Land Access Deal With Farmers, ABC Rural, 28 March 2014. Retrieved 1 April 2014 from <http://www.abc.net.au/news/2014-03-28/santos-aglagreement/5352090>.

Hoare, R., Shannon, N., Studdart, J. and Finn, W., 2014: The Impact of CSG on Our Water Resources: What Does the Future Hold?, Water: Journal of the Australian Water Association 41, 32-34. 
Holmes, J., 2014: Explorations in Australian Legal Geography: The Evolution of Lease Tenures as Policy Instruments, Geographical Research 52, 411.

Hough, C., 2014: Queensland Grazier Wins Landmark CSG Decision, ABC Rural, 12 February 2014. Retrieved 12 February 2014 from <http://www.abc.net.au/news/2014-02-12/csg-law/5255628>.

Howe, N., 2008: Thou Shalt Not Misinterpret: Landscape as Legal Performance, Annals of the Association of American Geographers 98, 435-460.

Hudgins, A. and Poole, A., 2014: Framing Fracking: Private Property, Common Resources and Regimes of Governance, Journal of Political Ecology 21, 303-319.

Hunter, T., 2014: The Role of Regulatory Frameworks and State Regulation in Optimising the Extraction of Petroleum Resources: A Study of Australia and Norway, The Extractive Industries and Society 1, 48-58.

Hunter, T., 2011: Shale Gas Resources in Western Australia: An Assessment of the Legal Framework for the Extraction of Onshore Shale Gas, eLaw Journal: Murdoch University Electronic Law Journal, 18, 29-52. Retrieved 29 May 2014 from $<$ https://elaw.murdoch.edu.au/index.php/elawmurdoch/article/viewFile/99/50>.

Ingleby, R. and Johnstone, R., 1995: Invocation and Enforcement of Legal Rules. In R. Hunter, R. Ingleby and R. Johnstone (eds) Thinking About Law: Perspectives on the History, Philosophy and Sociology of Law. Allen and Unwin, Sydney, 157-173.

Jacquet, J. and Stedman, R., 2011: Natural Gas Landowner Coalitions in New York State: Emerging Benefits of Collective Natural Resource Management, Journal of Rural Social Sciences 26, 62-91.

Jepson, W., 2012: Claiming Space, Claiming Water: Contested Legal Geographies of Water in South Texas, Annals of the Association of American Geographers 102, 614-631.

Jessup, B., 2013: Environmental Justice as Spatial and Scalar Justice: A Regional Waste Facility or a Local Rubbish Dump Out of Place?, McGill International Journal of Sustainable Development Law and Policy 9, 71-107. 
Jones, M., 2006. Landscape, Law and Justice - Concepts and Issues, Norsk Geogrisk Tidsskrift Norwegian Journal of Geography 60, 1-14.

Kedar, A., 2014: Expanding Legal Geographies: A Call for a Critical Comparative Approach. In I. Braverman, N. Blomley, D. Delaney and A. Kedar (eds) The Expanding Spaces of Law: A Timely Legal Geography. Stanford University Press, Stanford, 95-119.

Keenan, S., 2013: Property as Governance: Time, Space and Belonging in Australia's Northern Territory Intervention, The Modern Law Review 76, 464-493.

Keogh, L., 2013: The First Four Wells: Unconventional Gas in Australia, M/C Journal: A Journal of Media and Culture 16, no page numbers. Retrieved 16 May 2014 from <http://journal.mediaculture.org.au/index.php/mcjournal/article/viewArticle/617>.

King, J., Bell, L. and Bernard, J., 2013: Don't Kill The Golden Goose Before It Lays An Egg - Time To Review Restrictions on The Unconventional Gas Sector, Corrs Chambers Westgarth Lawyers, 5 August 2013. Retrieved 8 June 2014 from <http://www.corrs.com.au/thinking/insights/dont-kill-thegolden-goose-before-it-lays-an-egg-time-to-review-restrictions-on-the-unconventional-gas-sector/>.

Lacey, J. and Lamont, J., 2013: Using Social Contract to Inform Social Licence to Operate: An Application in the Australian Coal Seam Gas Industry, Journal of Cleaner Production, 831.

Lamacraft, T., 2014: Santos Lobbied For 'No Go' Area Reduction, ABC News, 17 July 2014. Retrieved 24 July 2014 from http://www.abc.net.au/news/2014-07-17/santos-lobbied-for-22no-go22-areareduction/5605030.

Lipscomb, C., Wang, Y. and Kilpatrick, S., 2012: Unconventional Gas Development and Real Estate Valuation Issues, The Review of Regional Studies 42, 161-175.

Locke, S., 2014: Legal Advice About CSG Contamination of Food Not Disclosed, ABC Rural, 26 March 2014. Retrieved 26 March 2014 from< http://www.abc.net.au/news/2014-03-26/beefcontamination-legal-advice/5346640>. 
Lloyd, D., Luke, H. and Boyd, W.E., 2013: Community Perspectives of Natural Resource Extraction: Coal Seam Gas Mining and Social Identity in Eastern Australia, Coolabah 10, 144-164.

Lock the Gate Alliance, 2014: Lock Your Gate. Retrieved 20 May 2014 from <http://www.lockthegate.org.au/lock your gate>.

Luke, H., Lloyd, D., Boyd, W. and Den Exter, K., 2014: Unconventional Gas Development: Why a Regional Community Said No: A Report of Findings from the 2012 Lismore City Council Election Poll and Exit Poll Survey (New South Wales), Geographical Research 52, 263-279.

Manning, P., 2012: What the Frack?: Everything You Need to Know About Coal Seam Gas. University of New South Wales Press, Sydney.

Mantle Mining Corporation, 2014a: December 2013 Quarterly Activities Report, 24 January 2014. Retrieved 30 May from <http://www.mantlemining.com/wp-content/uploads/2014/01/140124Quarterly-Activities-Report.pdf $>$.

Mantle Mining Corporation, 2014b: Trafford. Retrieved 29 May 2014 from $<$ http://www.mantlemining.com/project/trafford/>.

Mantle Mining Corporation, 2013: Positive Progress Achieved At Mount Mulligan, 13 November 2013. Retrieved 30 May 2014 from <http://www.mantlemining.com/wpcontent/uploads/2013/11/1276782.pdf>.

Mantle Mining Corporation, 2012: ASX Release: Mt Mulligan ILUA Authorised, 20 July 2012. Retrieved 29 May 2014 from <http://www.mantlemining.com/wpcontent/uploads/announcements/1129001.pdf>.

Martin, D., Scherr, A. and City, C., 2010: Making Law, Making Space: Lawyers and the Production of Space, Progress in Human Geography 34, 175-192.

Martin, D. and Scherr, A., 2005: Lawyering Landscapes: Lawyers as Constituents of Landscape, Landscape Research 30, 379-393. 
Matthews, O.P., 1997: Geography, Law, and Mineral Development. In G.L. Thompson, F.M. Shelley and C. Wije (eds) Geography, Environment, and American Law. Colorado University Press, Niwot, 104-119.

McGauran, C., 2013: Victorian Moratorium on Fracking Extended Until Mid 2015, ABC Rural, 21 November 2013. Retrieved 5 June 2014 from <http://www.abc.net.au/news/2013-11-21/nrnfracking-moratorium-extended/5107780>.

McManus, P. and Connor, L., 2013: What's Mine is Mine(d): Contests of Marginalisation of Rural Life in the Upper Hunter Valley, NSW, Rural Society 22, 166-183.

Measham, T.G. and Fleming, D.A., 2014: Impacts of Unconventional Gas Development on Rural Community Decline, Journal of Rural Studies, http://dx.doi.org/10.1016/j.jrurstud.2014.04.003.

Mercer, A., De Rijke, K. and Dressler, W., 2014: Silences in the Boom: Coal Seam Gas, Neoliberalizing Discourse, and the Future of Regional Australia, Journal of Political Ecology 21, 279-302.

Metgasco, 2014: Metgasco Initiates Legal Action, 3 June 2014. Retrieved 4 June 2014 from $<$ http://www.metgasco.com.au/asx-announcements/metgasco-initiates-legal-action>.

Munro, S., 2012: Rich Land, Wasteland. Macmillan, Sydney.

Nevins, J., 2004: Contesting the Boundaries of International Justice: State Countermapping and Offshore Resource Struggles Between East Timor and Australia, Economic Geography 80, 1-22.

New South Wales Office of Coal Seam Gas, 2014: Statements on Megasco PEL 16, 26 June 2014. Retrieved 20 November 2014 from <http://www.resourcesandenergy.nsw.gov.au/landholders-andcommunity/coal-seam-gas/community/statement-on-metgasco>.

North Queensland Lock the Gate Alliance Affiliate Group, email 9 June 2014. 
Organ, M., 2014: New Tactics See Coal Seam Gas Protests Gain the Upper Hand, The Conversation, 28 May 2014. Retrieved 10 June 2014 from <http://theconversation.com/new-tactics-see-coalseam-gas-protests-gain-the-upper-hand-26645>.

Pearse, G., McKnight, D., and Burton, B., 2013: Big Coal: Australia's Dirtiest Habit. University of New South Wales Press, Sydney.

Petroleum (Onshore) Act 1991 (NSW).

Petroleum (Production and Safety) Act 2004 (Qld).

Plenty v Dillon (1991) 171 Commonwealth Law Reports 635.

Plumb, J., 2013: Taking on Legal Challenges for Resource Exploration in Queensland, February 2013, Gas Today. Retrieved 15 March 2014 from

$<$ http://gastoday.com.au/news/taking on legal challenges for resource exploration in queensla nd/080305/>.

Plumb, J. and Shute, A., 2014: Negotiated Access to Land in Queensland - is this the end of ADR?, Carter Newell Lawyers, January 2014. Retrieved 14 May 2014 from $<$ http://www.carternewell.com/publications/resources/negotiated-access-to-land-in-queensland\%E2\%80\%93-is-this-the-end-of-adr.aspx>.

Pruitt, L., 2014: The Rural Lawscape: Space Tames Law Tames Space. In I. Braverman, N. Blomley, D. Delaney and A. Kedar (eds) The Expanding Spaces of Law: A Timely Legal Geography. Stanford University Press, Stanford, 190-214.

Queensland Government, 2012: Djungan People's Native Title Rights Recognised, 2 August 2012. Retrieved 10 June 2014 from <http://statements.qld.gov.au/Statement/ld/80044>.

Reghenzani, K. and Vlasiic, K., 2014: Coal Seam Gas Protest at Mareeba Over Exploration on Site of Mining Disaster, The Cairns Post, 29 May 2014. Retrieved 1 June 2014 from< 
http://www.cairnspost.com.au/news/coal-seam-gas-protest-at-mareeba-over-exploration-on-siteof-mining-disaster/story-fnipvlcp-1226935955114>.

De Rijke, K., 2013a: The Agri-Gas Fields of Australia: Black Soil, Food, and Unconventional Gas, Culture, Agriculture, Food and Environment 35, 41-53.

De Rijke, K., 2013b: Hydraulically Fractured: Unconventional Gas and Anthropology, Anthropology Today 29, 13-17.

Schweinsberg, S. and Wearing, S., 2013: Coal Seam Gas and Its Impacts on Destination Image Assessment: An Investigation into Wine Tourism in the Hunter Valley, NSW, in Proceedings of the $23^{\text {rd }}$ Council of Australasian University Tourism and Hospitality Education Conference 2013: Tourism and Global Change - On the Edge of Something Big, eds J. Fountain and K. Moore, Christchurch, New Zealand, Lincoln University, 11-14 February 2013, 717-722.

Sherval, M. and Hardiman, K., 2014: Competing Perceptions of the Rural Idyll: Responses to Threats from Coal Seam Gas Development in Gloucester, NSW, Australia, Australian Geographer 45, 185203.

Sherval, M. and Graham, N., 2013: Missing The Connection: How SRLU Policy Fragments Landscapes and Communities in NSW, Alternative Law Journal 38, 176-180.

Simonelli, J., 2014: Home Rule and Natural Gas Development in New York: Civil Fracking Rights, Journal of Political Ecology 21, 258-278.

Smith, A., 2006: Defending the Unpopular Down-Under, Melbourne University Law Review 30, 495553.

Smyth, R. and Mishra, V., 2011: The Transmission of Legal Precedent Across the Australian State Supreme Courts Over the Twentieth Century, Law and Society Review 45, 139-170. 
Stedman, R., Jacquet, J., Filteau, M., Willits, F., Brasier, K. and McLaughlin, D., 2012: Marcellus Shale Gas Development and New Boomtown Research: Views of New York and Pennsylvania Residents, Environmental Practice 14, 382-393

Stratford, E., 1993: Ideology, Environment and Legislation: South Australian Attitudes to Vegetation, Australian Geographical Studies 31, 14-25.

Stubbs, B.J., 2001: From 'Useless Brutes' to National Treasures: A Century of Evolving Attitudes Towards Native Fauna in New South Wales, 1860s to 1960s, Environment and History 7, 23-56.

Sugarman, D., 1994: Blurred Boundaries: The Overlapping Worlds of Law, Business and Politics. In M. Cain and C.B. Harrington (eds) Lawyers in a Postmodern World: Translationand Transgression. New York University Press, New York, 105-123.

Swayne, N., 2012: Regulating Coal Seam Gas in Queensland: Lessons in an Adaptive Environmental Management Approach, Environmental and Planning Law Journal 29, 163-185.

Tomasic, R., 1978: Towards a Typology of Lawyer Roles. In R. Tomasic (ed) Understanding Lawyers: Perspectives on the Legal Profession in Australia. Law Foundation of New South Wales and Allen \& Unwin, Sydney, 75-100.

Tuck, J., 2012: Mobility or Immobility: Reputation and Property Rights in the Mining Industry, University of Ballarat Business School Working Paper Series: 003 - 2012, 1-13. Retrieved 12 April 2014 from <http://www.ballarat.edu.au/ data/assets/pdf file/0019/75025/Mobility-orImmobility-Reputation-and-Property-Rights-in-the-Mining-Industry.pdf>.

Villanueva, J., 2013: The Territorialization of the 'Republican Law': Judicial Presence in Seine-Saint Denis, France, PhD thesis, Syracuse University, New York. Retrieved 11 June 2014 from $<\underline{\text { http://surface.syr.edu/geo etd/79/>. }}$

Weir, M. and Hunter, T., 2012: Property Rights and Coal Seam Gas Extraction: The Modern Property Law Conundrum, Property Law Review 2, 71-83.

Williams, J., Stubbs, T. and Milligan, A., 2012: An Analysis of Coal Seam Production and Natural Resource Management in Australia: A Report Prepared for The Australian Council of Environmental 
Deans and Directors, John Williams Scientific Services Pty Ltd, Canberra, 1-111. Retrieved 6 August 2014 from:

http://www.wentworthgroup.org/uploads/An\%20analysis\%20of\%20CSG\%20production\%20and\%20 NRM\%20in\%20Australia\%200ct\%202012\%20FULL.pdf. 